Original Research Paper

\title{
Aplikasi Tenologi Metode Topikal Pada Pemijahan Ikan Nila Sebagai Upaya Produksi Benih
}

\author{
Nursanti Abdullah"*, M.Abjan Fabanyo ${ }^{2}$ \\ ${ }^{1}$ Program Studi Budidaya Perairan Fakultas Perikanan dan Kelautan Universitas Khairun Ternate, Ternate, \\ Indonesia. \\ ${ }^{I}$ Program Studi Manajemen Sumberdaya Perairan Fakultas Perikanan dan Kelautan Universitas Khairun Ternate, \\ Ternate, Indonesia.
}

https://doi.org/10.29303/jpmpi.v3i2.1010

Sitasi: Abubakar, S., Abdul, K. M, Serosero, R. H, Subur. R, Widiyanti. S.E, Susanto. A. N \& Rina. (2021). Pemanfaatan Limbah Cangkang Kerang Untuk Produk Kerajinan Tangan Masyarakat Pesisir. Jurnal Pengabdian Magister Pendidikan IPA, 4(4)

\section{Article history}

Received: 15 September 2021

Revised: 20 September 2021

Accepted: 27 September 2021

*Corresponding Author:

Nursanti Abdullah, Program

Studi Budidaya Perairan

Fakultas Perikanan dan

Kelautan Universitas Khairun

Ternate, Ternate, Indonesia.

Email:

nursantiabdullah7@gmail.com

\begin{abstract}
Topical method technology is one of the methods that is trying to be developed to stimulate spawning and can overcome stress in small fish. The purpose of PKM is to help partner groups and local communities to produce their own seeds. From this PKM activity, it has been proven that partner groups and local communities have succeeded in spawning fish with the application of Topical method technology. From several treatments that were tested with TMT and hormones as stimulants, fish spawned with a degree of ovulation of $85 \%$ and SR larvae for 7 days of observation of $75 \%$.
\end{abstract}

Keywords: Teknologi Metode Topikal, Ikan nila, Benih.

\section{Pendahuluan}

Kota Ternate merupakan salah satu Kota yang berada di Profinsi Maluku Utara yang memiliki potensi sumberdaya alam dan sumberdaya manusia. Sumberdaya alam ini dapat dikembangak oleh masyarakat sebagai upaya pengambangan ekonomi diberbagai bidang termasuk bidang perikatan budidaya. Pengembangan perikanan budidaya di Kota Ternate sangat menjajikan pasar hal ini terbukti dengan meningkatnya permintaan akan ikan komsumsi air tawan khusunya ikan nila. Ikan nila sangat digemari oleh masyarakat Kota Ternate karena daging yang lejat dan guri serta memiliki kandungan protein yang cukup tinggi untuk nutrisi masyarakat Kota Ternate dan sekitranya. Namun permintaan akan komsumsi ikan nila ini sering tidak terpenuhi karena minimnya para pembudidaya di Kota Teranate dalam mendapatkan benih ikan nila.
Permasalahan yang dihadapi pembudidaya ikan nila dalam pengembangan perikanan budidaya Kota Ternate adalah ketersediaan benih untuk budidaya ikan nila sangat terbatas. Selain itu, pengadaan benih ikan nila dari luar daerah menjadi kendala besar, terutama modal yang dikeluarkan sangat tinggi, sehingga seringkali tidak seimbang dengan hasi panen yang didapatkan para pembudidaya. Budidaya ikan merupakan salah satu aspek yang berpotensi dan mulai digemari oleh masyarakat luas sehingga dapat dijadikan sebagai pekerjaan tetap yang mampu meningkatkan pendapatan keluarga. Faktor produksi yang sangat menentukan dalam usaha budidaya ikan adalah benih.

Benih merupakan salah satu mata rantai terpenting dalam keberhasilan usaha budidaya tersedianya benih tidak terlepas dari ketersediaan stok induk. Teknologi Metode Topikal (TMT) terbukti dapat mempercepat proses peningkatan kematangan gonad dan pemijahan beberapa spesies 
ikan. Teknologi ini telah banyak diteliti dan diterapkan pada beberapa komoditas perikanan, baik air tawar, payau maupun air laut dan juga ikan hias yang ber ukuran kecil. (TMT) pada ikan relatif mudah untuk dilaksanakan oleh masyarakat, karena cukup sederhana dan peralatan yang diperlukan tidak terlalu rumit atau sangat mudah didapat dan terjangkau. Tenologi Motode Topikal adalah salah satu metode yang coba dikembangan untuk mengatasi sters pada ikan-ikan yang berukuran kecil, (Abdullah 2007). Lutfiyah Al A. et.,al, 2019. Metode induksi insang topikal juga merupakan potensial sebagai teknik induksi pemijahan untuk ikan kecil. Teknik pemijahan mengunakan ovaorim secara topikal pada ikan mas koki (Carasius autratus) dengan ovaprim dapat memijah dalam waktu 5 jam (Abdullah,2007). Selain itu Metode topikal dengan mengunakan ovaprim sebagai perangsan juga dapat memijahkan hiu pelangi (Epalzeorhynchos eryth-rurus) berhasil dilakukan. Ovaprim adalah produk komersial yang merupakan kombinasi dari sGnRH-a (salmon gonadotropin hormon-analog) dan domper-idone (antidopamin) yang sering digunakan dalam induksi pemijahan ikan. Selain Metode Topialk adabeberapa metode yang digunakan untuk pemijahan ikan seperti teknologi induced sapauwnin (TIS).

Ahmad Taufik., et.,al 2019. Aplikasi TIS ini telah banyak dikembangkan menggunakan hormon perangsang yang telah resmi diperjualbelikan untuk penggunaan pemijahan semi buatan pada ikan. Pemanfaatan Teknologi Metode Topikal adala solusi untuk peningkatan efektifitas dan efisiensi pemijahan buatan telah dilakukan menggunakan berbagai hormon atau zat perangsang yang diberikan pada induk ikan, sehingga dapat mempercepat pematangan gonad (Mittlemark dan Kapuscinki, 2000). Salah satu metode yang digunakan adalah metode yang didasarkan pada rangsangan pelepasan gonadotropin (GTH). Pada prinsipnya penerapan Teknologi Metode Topikal (TMT) bermanfaat dalam upaya mempercepat sinkronisasi proses pematangan dan pemijahan ikan dalam memenuhi kebutuhan benih ikan air tawar, sehingga ketersediaan akan benih selalu tersedia. Berdasarkan latar belakang diatas maka pelaksanana program (PKM) pengabdian pada masyarakat dengan memanfaatkan Teknologi Metode Topikal dilakukan dengan harapan akhir dari kegiatan ini diharapkan masyarakat dapat produksi benih sendiri.

\section{Metode}

Metode kegiatan pada PKM dilakuan pada bulan Juni-Oktober 2021. Kegiatan ini dilaksanakan pada kelompok pembudidaya ikan nila di Danau Ngade kec. Kota Ternate Selatan Kota Ternate.

Metode pendekatan dalam pelaksanaan kegiatan ini adalah melalui transfer wawasan, iptek yang mudah untuk diaplikasikan serta dikembangkan oleh kelompok mitra yaitu Teknologi Metode Topikal (TMT)). Sarana tempat penyuluhan dan pelatihan serta praktek (demoplot) secara langsung untuk kegiatan ini telah tersedia di kelompok mitra.

Kegiatan dilakukan melalui beberapa tahapan, yaitu survai kondisi dan permasalahan yang dihadapi oleh kelompok mitra, penyampaian materi terkait teknologi pembenihan ikan, teknologi penijahan dengan menggunakan Teknologi Metode Topikal (TMT) ikan dalam budidaya ikan air tawar, monitoring dan evaluasi serta pendampingan pada kelompok mitra.

Berdasarkan hasil identifikasi masalah maka metode pemecahan permasalahan yang ada pada petani pembudidaya ikan di Danau Ngade adalah melalui pemberian materi, pengetahuan dan diskusi tentang seleksi induk ikan, pemijahan ikan baik alami maupun secara buatan, pengukuran dan monitoring kualitas air pemeliharaan.

Pada kegiatan ini menggunakan induk ikan nila jantan ukuran 400 gram dan nila betina 500 gram. Induk ikan nila yang dipakai dalam kegiatan ini sebnyak 70 ekor. Induk Jantan dan betina disuntik dengan hormon ovulasi dengan dosis 0,6 cc/grm berat tubuh induk. Pada saat praktek penyuntikkan hormon, Ovulasi diambil dengan menggunakan jarum suntik ukuran $1 \mathrm{~mL}$ lalu dilakukan pengenceran dengan menggunakan larutan $\mathrm{NaCl}$ fisiologis $0,85 \%$, selanjutnya dilakukan penyuntikkan pada bagian dorsal induk ikan dibawah sisik ikan. Para peserta diberi kesempatan untuk melakukan penyuntikan hormon ovulasi pada induk ikan nila. Induk ikan yang telah disuntik dengan hormone ovulasi dimasukkan kedalam bak pemijahan masing-masing. Bak pemijahan disiapkan dengan air bersih dan 
dilengkapi aerasi kecil di sekeliling bak yang berfungsi untuk meningkatkan kandungan oksigen terlarut. Selain itu didalam bak pemijahan dimasukan anyaman tali rafi yang berfungi sebagai tempat pelekat telur.

\section{Alat dan Bahan yang digunakan}

\begin{tabular}{|l|l|l|}
\hline No. & $\begin{array}{l}\text { Nama alat dan } \\
\text { bahan }\end{array}$ & Kegunaan \\
\hline 1. & Kovo 20 M & Sebagai Media \\
\hline 2. & Horiba & Pengukur Kualitas Air \\
\hline 3. & Spoit & Sebagai injeksen \\
\hline 4. & Ikan 70 ekor & Sebagai hewan uji \\
\hline 5. & Hormon & Sebagai perangsang \\
\hline 6. & Tali ravia & $\begin{array}{l}\text { Sebagai tempat pelekat } \\
\text { telur }\end{array}$ \\
\hline
\end{tabular}

\section{Hasil dan Pembahasan}

Sosialisasi pelaksaan kegiatan PKM dilakukan pada tanggal 20 juli 2021 di Danau Ngade (gambar 1) dengan melibatkan Mahasiswa dan petani pembudidaya ikan dan masyarakat setempat, sedangkan pemijahan dilakukan pada 2 lokasi yaiti di danau Ngade dan Laboratorium terpadu LIPI. Sosilisasi ini dilakukan untuk menginformasikan kegiatan yang akan dilakukan. Sosialisasi kegiatan PKM dibuka oleh ketua kelompok mitra yang dihadiri oleh mahasiswa, program studi BDP dan MSP, Masyarakat setempat dan kelompok mitra, didahului dengan penyampaian maksud dan tujuan kegiatan PKM ini dilakukan oleh tim kegiatan PKM.

Kegiatan sosialisasi berhasil dilakukan dengan baik dan kelompok mitra dan masyarakat setempat merespon kegeitan PKM ini dengan baik.

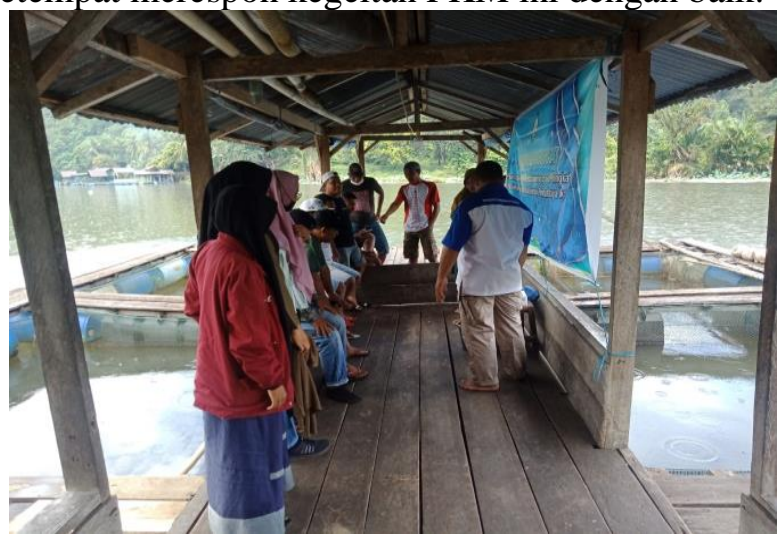

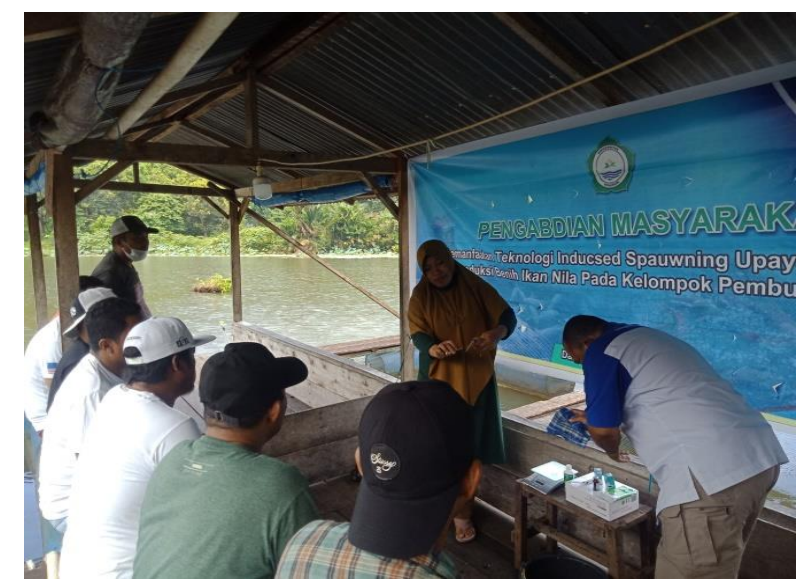

Gambar 1. Sosalisasi dan demontrasi di Danau Ngade.

\section{Pemijahan}

Pemijahan dilakukan pada dua tepat yaitu di Laboratorium terpadu (LIPI) dan di Danau Ngade. Pemijahan merupakan salah proses pelepasan telur diikuti dengan pengeluaran sperma sehingga terjadi proses pembuhan. Pemijahan dengan perangsang ovaprim dapat mempercepat ovulasi pemijaan. Keberhasilan pemijahan pada induk ikan dapat dipengaruhi oleh hormon dan fator lingkungan. Aziz (2018), tingkat keberhasilan ovulasi induk disebebkan oleh ikan yang akan disuntik dan setelah disuntik. Putra (2010) Selain pengaruh dari pemberiana hormo, ovulasi juga dipengaruhi oleh lingkungan. Ovulasi dapat terjadi karena adanya sinyal lingkungan yang diterima oleh sistem syaraf pusat yang kemudian diteruskan ke hipotalamus selanjutnya hipotalamus merespon dengan cara melepaskan GnRH untuk merangsang produksi LH dan FSH Vinka, et., al 2021. Selanjutnya akan terjadi pematangan yang menyebabkan telur bermigrasi kearah mikrofil dan setelah itu lapisan paerikel pecah dan telur keluar menuju rongga ovary terjadi ovulasi pemijahan.

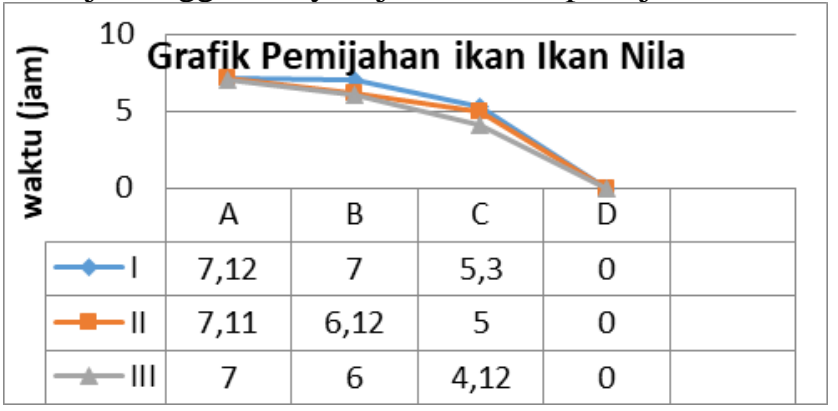

Gambar.2 Grafik pemijahan 

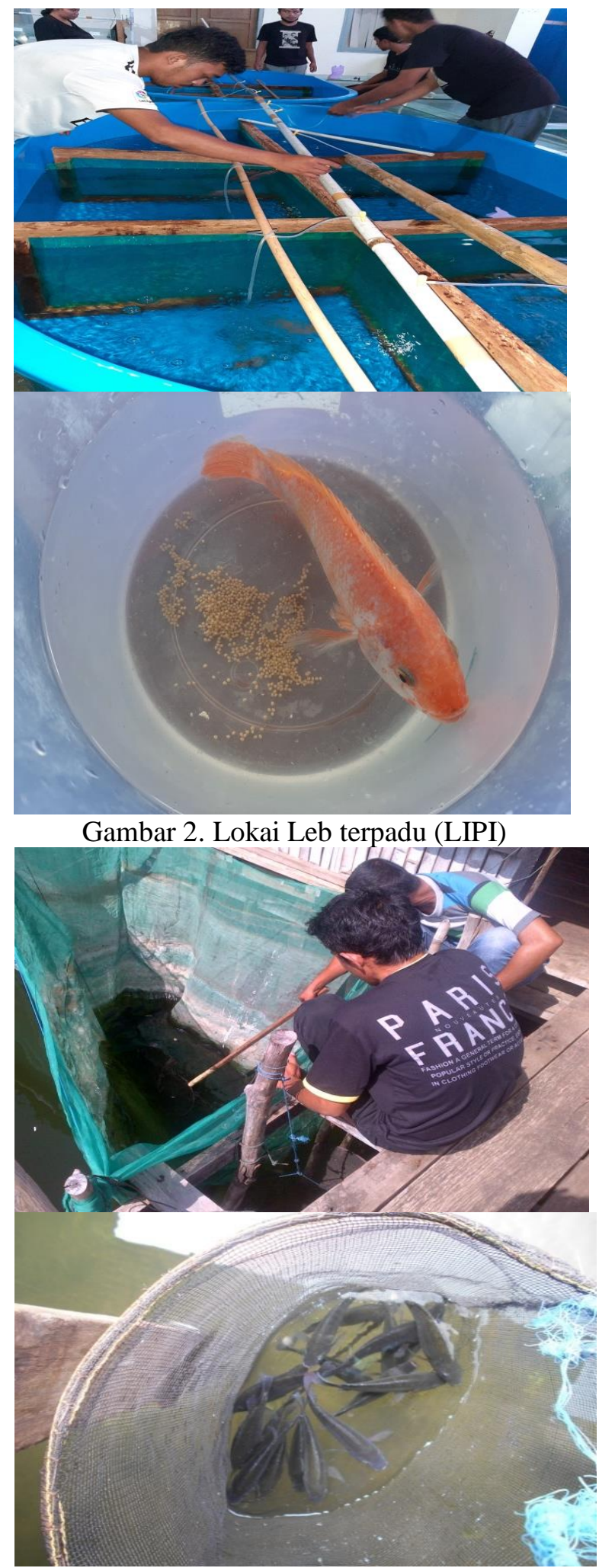

Gambar 3.Pemijahan Lokasi Danau Ngade

\section{Kesimpulan}

Kegiatan PKM ini kelompok mitra dengan masyarakat setempat dapat menerima dan mengaplikasikan Teknologi Metode Topikal ini dengan baik dan benar sehingga dapat menghasilkan pemijahan dengan derajat penetasan $85 \%$ dengan kelansungan hidup larva selama 7 hari sebesar $75 \%$.

\section{Daftar Pustaka}

Aziz, M.I.A. 2018. Performa Reproduksi dan Pemijahan Ikan Jelawat (Leptobarbus hoevenii) yang DisuntikHormonHCG. Skripsi. Universitas Lampung, Lampung.

Akhmad Taufiq Mukti1*, Ahmad Shofy Mubarak2, dan Endang Tri Wahyurini, 2019 Aplikasi Teknologi Inducid Spawning Untuk Mempercepat Pemijahan Ikan Lele. Pada Mitra Program Kemitraan Masyarakat. Journal of Aquaculture and Fish.

Lutfiyah Al Adawiyah , Laksmi Sulmartiwi, Türker Bodur, Darmawan Setia Budi

Mittlemark, J. and Kapuscinki, A., 2019. Induced reproduction in fish. Minnesota Sea Grant. University of Minnesota, USA. 12 p. Jurnal Triogenology.

Mittlemark, J. And Kapuscinki, A, 2000 Induced Reproduction in Fish Minnesota Sea Grant. University Of Minneseta.

Nursanti A, 2007. Efektifitas Pemberian Hormon Ovaprim Secara Topikal terhadap Proses Ovulasi Pemijahan Ikan Mas Koki (Carasius auratus). Tesis Pasca Sarja IPB

Putra, R.M. 2010. Pengaruh Kombinasi Penyuntikan HCG dan Ekstrak Kelenjar Hipofisa Ikan Mas terhadap Daya Rangsang Ovulasi dan Kualitas Telur Ikan Pantau (Rasbora lateristriata Blkr). Jurnal Perikanan dan Kelautan, 15(1):1-15.

Vinka Leonita, Deny Sapto Chondro Utomo, Hilma Putri Fidyandini, 2021. Uji Komparatif Hormon Ovaprim, Spawnprim, dan HCG pada Proses Pemijahan Ikan Patin Siam (Pangasianodon hypophthalmus). 